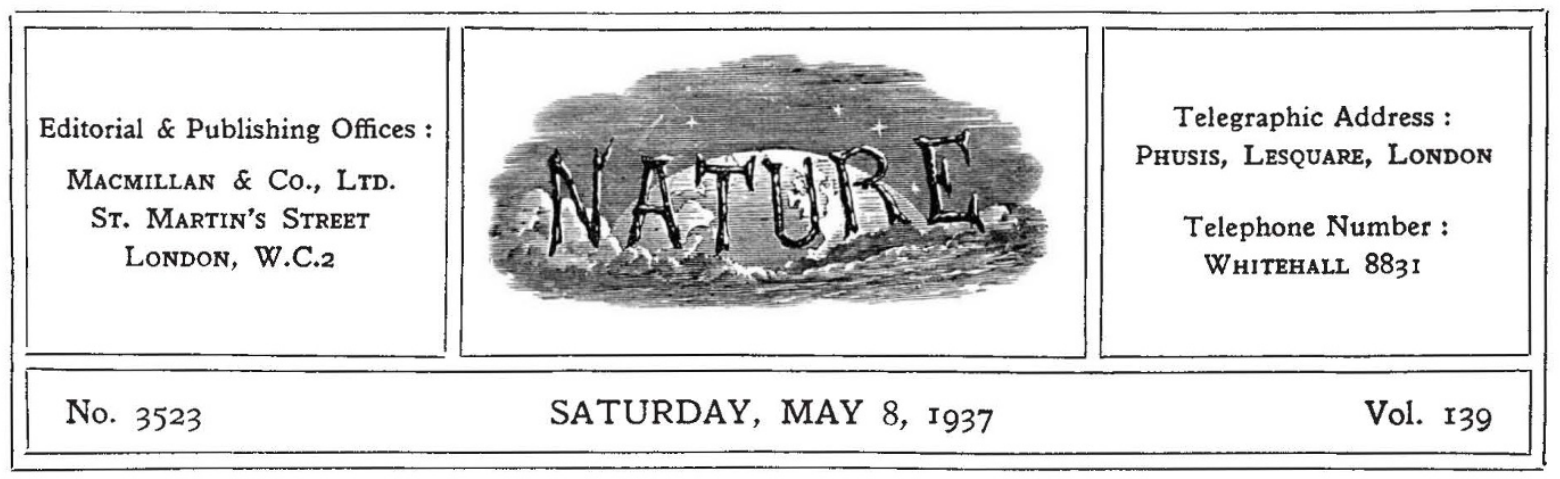

\title{
The Ceremonial of Coronation
}

$\mathrm{I}^{\mathrm{N}}$ the ceremonial and pageantry of coronation, such as that now at hand, there draws to a close a period of transition in which the royal power passes from dead to living. The solemn investiture of the new monarch with the symbols of kingly dignity and the acclamation and rejoicings of his people mark the final stage in a ritual of change, which, from the earliest days of primitive kingship, has been held of gravest moment for the community. Although we may no longer believe with our primitive forefathers, as still do some of the less-advanced peoples of to-day, that the vigour and fertility of crops and herds, and even the prosperity of the nation, may depend directly upon the virility of the ruler, this much of the mystical lingers in our mode of thought, that only with the ceremonial of coronation do we feel that we have passed in full sense from waters, which might prove turbulent, to the haven of a new reign.

To the coronation of His Majesty King George VI, must be attached an added significance over that of his predecessors. The change in the interrelation of the constituent parts of the Empire under the provisions of the Statute of Westminster has thrown into high relief the personal responsibility which now rests upon the King-Emperor as the sole constitutional link of Empire. For the first time the Coronation Oath, in its amended form, assumes a position of outstanding import in the ceremonial observances. It has become something more than the solemn undertaking to make just use of the royal prerogative than it has been in the past. In the imperial sense, it is now the head and front of the rite.

This process of evolutionary development, which we see taking place before our eyes, is in full accord with the history of the ceremonial of coronation in Great Britain. Like the British constitution, of which it is an appanage, its ability to endure rests on its capacity to change without break in continuity. So far from being a collection of survivals, the coronation ceremonial, even though close parallels may be cited from ancient pagan custom and the practices of 'savages', in each of its rites expresses some one aspect or another of the emotional force which inspires workaday citizenship. Each change in form, and more especially each variation in emphasis as between the elements in the ceremonial, to be marked in the course of its history, has expressed the general sense of the community at that period in its reactions of loyalty towards the monarch, successively as head of the English State, as ruler of the United Kingdom, and as King-Emperor of the Empire.

The British ceremonial of coronation, like the monarchy, is the oldest in the European States which still adhere to the monarchical form of government. It is also the most elaborate. Its history begins in the eighth century with an Anglo-Saxon rite, in which the ceremony of sacring the king was introduced in the middle of a Mass. Oil was poured from a horn on the king's head, the anthem "Zadok the Priest" was sung, the bishops and nobles placed a sceptre in the king's hand, the staff was delivered to him, and finally a helmet was placed upon his head. The assembly then cried "May King . . . live for ever'. The enthronement followed, and the nobles swore fealty. The Mass then concluded with special prayers.

In part, and especially in so far as it was an enthronement with acclamation, this ceremony 
was of much earlier origin. The Germanic tribes, after the election of their ruling chief, used to enthrone or elevate him on their shields. He was then carried on the shields around the assembled people on the shoulders of certain of the nobles. This custom was adopted by the Franks, and was the method by which Clovis and his immediate successors were elevated to the throne. It continued in use for some time after the introduction of Christianity with the addition of a religious service. It survived in part in the procession from the Tower to Westminster and the elevation to the marble throne in the English ceremony, and in France in the showing of the king to the people.

The tribal ceremonial, in which the elected chief was elevated on the shields of his subjects, in accordance with the needs of the times, symbolized his function as leader of his people, more especially in war. With the coming of Christianity and the participation of the Church in affairs of State, another aspect of kingship, no less primitive, was brought into prominence in the inaugural ceremony. This was the spiritual and magico-religious element, which in early and primitive forms of the kingship identifies the ruler with divinity or accredits him with magical powers to be used for the benefit of his people. In the coronation ceremonial of Western Europe, its immediate source must be sought in the Bible, and as time went on in the Eastern conceptions of monarchy which came with Byzantine influence, rather than directly in survivals of pagan ideas. For although pagan chiefs and rulers claimed descent from heathen deities and demi-gods, such as Odin or Wotan, neither English monarchs nor His Most Christian Majesty of France appear to have laid claim to divinity, but rather to rule through divine influence-by the grace of God. At the same time, a detailed comparison with non-Christian rites indicates so many similarities in form and idea as to suggest at least a strong colouring of a mode of thought, which belongs to a more primitive phase of religious belief. As is well known, the early Church was not averse from adapting the concepts and ideas of paganism to further the advancement of Christianity.

It is a reasonable assumption that the magicoreligious conceptions, which Sir James Frazer has shown to play a predominant part in the evolution of early forms of kingship, should be much in evidence at the inauguration of a new ruler. The problem before the primitive mind must always have been how best to ensure that the qualities and powers, which secured in the ruler who has now passed away the prosperity of his people, should be continued in the person of his successor. When the succession was determined by mortal combat, in which the victor either remained, or became, the ruler, as in the priesthood of Nemi, the result determined the issue. Where the cult of the ancestors prevailed, especially when the spirit of an ancestor was believed to reappear on earth in his descendants, as among certain of the Bantu-speaking peoples, the principle of inheritance was adequate to their need. Failing the direct assurance of such determinants, however, it was deemed necessary, as we can see from the character of the inaugural rites themselves, to ensure the continuance of the qualities and powers of the old ruler in the new by a ceremonial which in its origin and essence was magical, or at best magico-religious, however it may have come to be regarded later, when incorporated in a more advanced system of religious belief.

In royal and chiefly inaugural ceremonies which are of a traditional character and not modern innovations, there are certain recurring features, some appearing sporadically, others again and again with regularity. Mr. A. M. Hocart in his acute and ably argued study of the kingship (Oxford, 1927), analysing this ceremonial, notes some twenty-six characteristic features. His analysis is too long to quote here; but the most important point he makes is that the ceremonial is one in which the ruler dies, and is born again as a god. Among other characters may be men. tioned a ritual combat in which the ruler must prove victorious, baptism with water and anointing with oil, investiture with special garments and regalia, the enthronement, the acclamation of the people, the sacrifice of a victim-often human-and usually the bestowing of a new name on the king.

Lest it seem that the interpretation of the coronation ceremonial as a re-birth is somewhat remote from the form of rite with which most are familiar, it may not be out of place to refer briefly to one or two examples which support this contention. Only the more significant points are mentioned.

In the ceremony of inauguration of a ruling chief in Fiji, which Mr. Hocart quotes as his 'type specimen', a specially prepared sheet of bark. cloth is wrapped round the chief's arm, and a bowl of kava is presented to him, after a period of fasting and abstinence. When he drank this, he was not permitted to take the bowl with the 
arm which had been swathed in the bark-cloth sash. For four nights kava was made; and at the end of that period the chief bathed, while a raid on a village secured a human victim who was killed, baked and eaten at a feast. At one point in the proceedings a man offered to fight as a champion for the chief. Muskets were fired so that the whole land might know that the ceremony was completed.

The points of interest in connexion with this ceremonial are that in part it is similar to the ritual which is observed on the death of a chief, while the ceremonial drinking of kava, and the bark-cloth scarf, apparently are intended to suggest that the god is brought to the chief in the bark-cloth and enters his body after he has died in the form of the kava. He is then born again and bathes to cleanse himself from the impurities of the womb.

The theory that the inauguration of a chief or king is a new birth is more clearly brought out in the ancient Indian ritual, in which the priest in investing the king with three garments speaks of two of them as cauls out of which he is born, while the mantle which is thrown over him last of all, is called "the womb of sovereignty". In this ceremony there is a magical victory in a mock fight, while the climax of the rite is a lustration of the enthroned king with a double stream of water. This purification by water is followed by an anointing with clarified butter.

Although little is known of the actual coronation rites of Ancient Egypt, the Sed festival, which took place at a late date in a reign, renewed the vigour of the monarch by a rebirth and rejuvenation in which the rites were in all prob ability a repetition of the rites of coronation.

The idea of continuity through rebirth is most clearly expressed, perhaps, in the ceremonies which accompany the accession of the Adah of Idah, northern Nigeria-a vigil of eight days at the royal necropolis; a period spent at the "birthplace", where the future ruler is joined by the chief wife of his predecessor; and the action of two officials who sport as man and wife, the latter then mimicking childbirth and delivering the Adah to the chief eunuch as 'her' son. The Adah is then divested of his birth garments and adorned with the royal robes.

While it is undoubtedly true that neither in France nor in England, as already mentioned, was it claimed that the king was divine, yet there are many similarities in detail with the ceremonies mentioned which are suggestive of at least a cognate mode of thought, and it may be even a more intimate connexion: the vigil-no longer observed-the anointing, the robing and investiture, the acclamation of the people, the perambulation, and the challenge of the king's champion, which takes the place of the ritual combat, though the office and not the rite alone remains.

Most significant, perhaps, in the older ritual is the ceremony of the anointing, which until the Reformation was the most important element in the ceremonial. By it, the person of the king was made sacred. Indeed it was held by some that the king henceforth was both priest and layman; and although this doctrine does not seem to have prevailed in England, in France the king appears to have held priestly office and on occasion is said to have officiated in priestly vestments. It is evident that in both the English and the French ceremonial the Divine Spirit and the kingly office were brought into peculiarly intimate relation. These two closely related forms of the rite, with the Empire, made use of the chrism, the most sacred of the blessed oils, in France mixed with a drop of oil from La Saincte Ampoule, in which the Holy Dove had once placed holy oil for the coronation of Clovis, in England from the time of Edward II, when the coronation ritual reached its most elaborate development, for anointing the parts of the king's body, while for his head was used oil from the flask which, as the Pope wrote to Edward, the Virgin Mary had delivered to Thomas à Becket for that use at some later day. From this anointing the two monarchs derived their power of healing by 'touching' for the King's Evil.

With the Reformation and the personal rule of the Tudors, the idea of the sanctification of the king's person gave place to other concepts of monarchy. The importance of the unction waned to give place to the ceremonial of placing on the monarch's head the crown, the symbol of territorial dominion, as had been shown by the triple crown of Charlemagne, silver for Germany, gold for Rome, and the sacred crown of iron, made from a nail of the Cross, for Lombardy. The crown, it is true, is not without a 'magic' of its own-otherwise why should our kings still be crowned with the crown of St. Edward, though that venerable relic was broken up under the Commonwealthbut its real significance lies not in its interpretation as a survival, but in its living meaning as an emblem of a constitutional and personal relation between king and people. 